\title{
Dissolution of the Commercial Companies due to the Passing of Time Established as a Duration of the Company - Theoretical and Practical Aspects
}

\author{
Cornelia LEFTER \\ Bucharest Academy of Economic Studies \\ cornelialefter@ase.ro \\ Ovidiu Ioan DUMITRU \\ Bucharest Academy of Economic Studies \\ office@ovidiuioandumitru.ro
}

\begin{abstract}
At the creation moment of a commercial company, the partners have the obligation, according to Law of commercial companies, to establish its functioning duration. This duration can be limited or unlimited. The fulfillment of the time for which the company was established imposes its legal dissolution. This kind of dissolution produces specific effects that, during the time, have made the object of theoretical and practical controversial debates that we try to explain here.
\end{abstract}

Keywords: dissolution de jure; voluntary winding up; commercial companies; duration of the company's existence; duration prolongation.

JEL Code: K22.

REL Codes: 5D, 14K. 
Active participants to the economic circuit, the commercial companies do not have, however, an eternal existence, although, at their creation, the associates decide that they shall function for an unlimited period of time.

But, as the associates have the freedom to establish the creation of the company, they can, also, decide its winding up, including the limitation of its duration of existence. This is why, the first general dissolution cause regulated by the provisions of law regarding the commercial companies is the expiration of the term established as a duration of the company (art. 227 letter a).

According to the provisions of New Civil Code, and of art. 7 and 8 from Law 31/1990, within the constitutive act of the company, the associates shall establish very clear the period of time for which it was created. The lack of such a provision does not, however, represent a reason to reject the incorporation of the commercial company. In connection with this aspect, the juridical doctrine considered that the lack of express provision regarding the duration of the company is equal with the will of the partners to grant an indefinite (unlimited) life period to the company, and this decision is the attribute of those that are creating a company and not of the Director of the Register of Trade Office or of the court of law (Roş, 1996, p. 58)

Lengthways the time, this dissolution cause was considered by the juridical doctrine as being the only situation when the dissolution of a trade company occurs de jure, while all the others causes provided by law have defining elements that include them in other forms of dissolution (we do not refer here to the situation when the dissolution occurred due to the nonchanging of the incorporation certificate, only because this was a state intervention, at a particular moment, a solution imposed to the associates).

Thus, some authors have asserted that the fulfillment of the time for witch the company was created leads to its dissolution de jure without the court or the partners' intervention (Căpățână, 1996, p. 371). The fulfillment of the time for which the company was created is, as such, considered "the typical dissolution case that operates automatically" (Băcanu, 1997, p. 18.), without being necessary the adoption of a decision of the General Assembly of the partners, a court decision or the fulfillment of any formality for that.

The reason for which there is no need to achieve special formalities in order to declare the dissolution of the company for the fulfillment of its functioning duration is the fact that the dissolution publicity was carried-out from the very creation of the company through the publication in the Official Gazette of the constitutive act that comprised the clause regarding the company's duration. Thus, the dissolution must not be notified to third parties because, since the constitutive act was published, it is presumed that they 
know the period for which the company was created, and, consequently, they were aware about the limitation of the period of time for which the company was established, implicitly of the moment when this one expires (Băcanu, 1997, p.18).

A special situation is that when, through the constitutive act, the partners establish that the duration of the company is indefinite and, later, their General Assembly decides to limit it. Of course, the mention to modify the term is submitted to the same publicity procedure as the incorporation and has the same effects as the latter, and the dissolution de jure will also apply in this case (Georgescu, p. 710)

Taking into account the aforementioned issues, we must understand that, although through the limitation of the functioning duration, the dissolution appears, somehow, pre-established from the creation moment of the company, it is not the essence of the commercial company to be created with the view to be dissolved. Nevertheless, when the dissolution occurs, it appears as culminating point of the company's life, where the main object will be the patrimony liquidation and the erase of the company from the Register of Trade (Georgescu, 1948, p. 725).

Thus, by reaching the term, the company will be dissolved, and the administrators will have to start the liquidation procedure. As a consequence, the administrators will not be allowed to carry-out new operations on behalf of the company, otherwise, they will be severally and jointly liable for the operations they have carried-out.

In principle, after the expiration of the term for which the company was created, the associates can not extend its duration, and a contrary decision leads to the creation of a new commercial company. But, in reality, there were some cases, especially in the middle of '90s, when the courts of law admitted the extension of the company duration, although this decision of associates appeared after the expiration of the term provided by the constitutive act. This non-unitary practice gave rise to many debates within the Romanian doctrine regarding the interpretation of the provisions related to the extension of the company duration (Băcanu, 1997, p. 17).

If, after the expiration of the duration, the company is still functioning, it was considered, in one opinion (Cărpenaru, 2011), that we deal with a company irregularly created. According to another opinion, it was asserted that it would not be about a company irregular created, but about the engagement of the directors' liability for the operations committed by these ones (Şcheaua, 2002, pp. 461-462). 
If, in the light of the provisions of the former Commercial Code, it could also be taken into consideration the hypothesis of a company irregularly established, at present, after the modifications of the provisions related to the consequences of the breach of the legal requirements for the creation of a company, such an hypothesis is excluded, incurring the situation provided by art. 233 line 2 of Law no. 31/1990 according to which "from the dissolution moment, the directors, managers, respectively the board of directors must not carry-out new operations, otherwise, they will be severally and jointly liable for the operations they have accomplished".

Some authors (Vâlceanu, 1997, p. 35) have even laid down possible solutions to continue the activity or to transform the company that functions after the expiration of the initial duration. Among the solutions proposed there are mentioned the extension of the duration through the decision of the General Assembly of the partners and the merge followed by acquisition. It is obscure why only the merger followed by acquisition was accepted as dissolution modality without liquidation, when Romanian legislation, as well as EU legislation provide other forms that have the same effects. The same author (Vâlceanu, 1997, p. 35) upholds that this "cancellation cause" may be rectified "upon the request of the party concerned, either until the beginning of the liquidation procedure or until the delivering of the judicial decision", accepting clearly that this eventual prorogation should be carried-out after the expiration of the duration, but before the erase of the company from the trade Register.

We believe that these two explanations (respectively, that of the company irregularly established and that of continuing the activity after the expiration of the company duration through the prorogation of the term) cannot stand because they do not comply with the principles stated by Law no. 31/1990.

But, for this situation, the majority of courts ruled that the application for registration of mentions regarding the extension of the functioning duration of the company is inadmissible if at the date when the General Assembly decided the extension the functioning duration had expired, the company being dissolved de jure (Lupaşcu, 1999). Thus, it was held that, the only modality to prevent the company's dissolution is the express prorogation of its duration, under the condition that such a decision is taken before the fulfillment of the company functioning term.

It is obvious the fact that the prorogation of the company duration must comply with the publicity rules provided by the law for its incorporation. Thus, according to art. 204 from Law no. 31/1990, the modification of the period for which the commercial company was established must comply with all conditions regarding the modification of the constitutive act. 
Within the doctrine, there are divergent opinions related to the moment when the operations regarding the prorogation of the commercial company duration are considered accomplished. Thus, a majority opinion upholds that "the prorogation of the company duration produces effects only if it was accomplished before the duration of the company provided by the constitutive act has expired" (Cărpenaru, 2011, p. 137). However, other authors (Băcanu,1997, p. 22) assert that ,in the situation when the resolution of the statutory organs or, as the case may be, of the associates occurred, was published and remained final before the dissolution term, it should not be admitted that the decision of the court could be subsequent to the dissolution date".

We have to admit that a very restrictive interpretation of the legal provisions regarding the accomplishment of the formalities related to the prorogation of the company duration would lead to the creation of a negative trend that might affect the good functioning of commercial company and would sanction some situations of normality. A rigorous but correct interpretation of the above mentioned principles leads to the conclusion that all formalities regarding the extension of the commercial company duration must be registered in the Trade Register before the expiration of the company duration provided by the constitutive act.

In order to avoid an unexpected dissolution, the law imposes that the associates should be consulted regarding a possible extension, with at least three month before the expiration of the company duration. The aforementioned provision influenced by French law (art. 1844 - 6 paragraph (2) French Civil Code) must not be understood in the sense that it establishes a deadline, after which the extension of the company duration can not be decided. On the contrary, we consider that the prorogation of the company duration may be decided anytime, until the fulfillment of the term for which the company was created. Thus, we understand that the provision of art. 227 paragraph (2) of Law no. 31/1990 is meant especially to prevent the company dissolution due to the fact that the associates had not the time to extend its duration. It is, therefore, about a prevention measure meant to protect the partners and thee creditors.

If the company's directors fail to organize the consultation, upon the request of any associate, the court can order its performance. We shall mention the fact that the organization of the consultation does not prevent the company dissolution at the expiration of the duration provided by the constitutive act.

In addition to that, according to the legal provisions in force, the creditors of the associates within a partnership, limited partnership company or limited liability company can make opposition against the decision of the associates to 
extend the company duration above the term initially established, if they have rights established through a writ of execution previous to this decision. The opposition is made within 30 days from the date the decision or the amending addendum is published within the Official Gazette of Romania and is submitted to the Trade Register Office.

Within our old doctrine (Fințescu, 1929, p. 289) it was asserted the idea that in the situation when the memorandum of association does not establish the duration for which the company is created, any associate can claim the dissolution of the company considered to be unlawful created. In the light of Law no. 31/1990 this conclusion cannot stand, since the company may be created for an indefinite duration.

Regarding the prorogation of the company duration, even during the liquidation phase, there are controversial opinions that deal with this issue. Within one opinion (Băcanu, 1997, p. 20), it is considered that the assosiates may overturn, even during the liquidation phase, their decision about the dissolution and liquidation and may extend the company duration or may decide the merger with another company, unless the dissolution occurred due to the expiration of the term. Thus, the return concerning the dissolution is understood as a decision to create another company. A contrary opinion (Cărpenaru, 2002, p. 504) argues that, the rule according to which the company ceases on the dissolution date must not be understood ad literam, because otherwise it would not be seen how the operations of the company are continued on its behalf by the liquidators and how the associates could decide, during the liquidation period, a measure opposite to the liquidation. In addition, any party concerned may claim the establishment of dissolution, meaning the company's partners, the creditors or the personal creditors of the associates. The latter ones can claim the liquidation of the part owned by the associate, if they held claims previous to the expiration of the company duration, according to art. 66 paragraph (1) from Law no. 31/1990 (which stipulates that, during the company duration, the partner's creditors may exercise their rights only on the part of the corresponding benefits owned by the associate according to the balance sheet, and after the company dissolution, on his part resulting through liquidation). Another opinion (Tăbăltoc, 1993, p. 110) helds the fact that, the court will not grant dissolution before the fulfillment of the term for which the company was created if this brings prejudice to public order, such as the interests of the associates or of the creditors. Moreover, such a prejudice can not be alleged for in case of partnerships and limited partnership companies "that must last as long as the associates survive", because the company duration cannot 
depend on the whims of one of the associates that has, anytime, the freedom to claim for to be discharged of his contribution to the company's capital through selling or cession of his social parts (Vivante, 1929, p. 629).

Once the liquidation procedure started, the legal personality of the company survives only with the view to complete this procedure, without allowing the realization of operations that are not under way or related to the liquidation procedure.

The final stage of liquidation is the erase of the company from the Register of Trade and the liquidators are liable to apply for that. Within the doctrine (Băcanu, 1997, p. 18), it was alleged the fact that, in reality, the legal personality of the commercial company does not cease on the erase date, as, theoretically, it would be normally to happen, similar to the incorporation in the Register of Trade. In fact, the legal personality ceases on the publication date in the Official Gazette of the closure writ regarding the liquidation procedure, the erase having the mere role of evidence.

As a conclusion, we can assert that the dissolution of the commercial company upon the expiration of the term established for its duration (art. 227 letter a) of Law no. 31/1990) is, however, the only case of dissolution de jure. As far as the voluntary winding up, the dissolution for the fulfillment of the functioning duration appears as a decision of the partners taken through the memorandum of association or through the statute. The associates have established that the company should last a pre-established period of time and have agreed that, upon the expiration of this term, it should be wound up. According to the legal provisions, the interdiction to carry-out new operations applies from the dissolution moment, without distinguishing between dissolution de jure, voluntary or judicial dissolution.

The major difference resides in that fact that, as far as the voluntary winding up is concerned, the liquidation belongs to the associates' will, while in case of the dissolution de jure, the liquidation occurs automatically without the statutory organs or, as the case may be, the associates may decide otherwise after it has produced its effects. 


\section{References}

Băcanu, I., „Dizolvarea de drept a societăţii comerciale. Condiții de validitate a prelungirii duratei societății”, Revista de Drept Comercial, nr. 1/1997

Căpățână, O. (1996). Societățile comerciale, ediția a II-a, Editura Lumina Lex, Bucureşti

Cărpenaru, S.D. (2011). Tratat de drept comercial, ediția a II-a, Universul Juridic, Bucureşti

Cărpenaru, S.D. (2004). Drept comercial român, ediţia a VI-a, Editura All Beck, Bucureşti

Cărpenaru, S.D. (2002). Societățile comerciale, Editura All Beck, Bucureşti

Fințescu, I.N. (1929). Curs de drept comercial, vol. I, Bucureşti

Georgescu, I.L. (1948). Drept comercial român, Editura Socec, vol. II, Bucureşti

Georgescu, I.L., Societăți comerciale, vol. II

Lupaşcu, D. (1999). Culegere de practică judiciară în materie comercială a Tribunalului Bucureşti pe anii 1990-1998, Editura All Beck, Bucureşti

Roş, V., „Dizolvarea societăţilor comerciale. Particularităţi ale dizolvării pe cale judiciară. Lichidarea societăţilor comerciale. Momentul în care intervine. Rolul instanței de judecată în cursul lichidării societății”, Revista de Drept Comercial, nr. 1/1996

Şcheaua, V.M. (2002). Legea societăţilor comerciale, Editura Rosetti, Bucureşti

Tăbăltoc, D.M., „Contribuții la clarificarea unor probleme ivite în aplicarea de către instanțele judecătoreşti a Legii nr. 31/1990”, Revista de Drept Comercial, nr. 6/1993

Vâlceanu, Gh.C., „Unele aspecte privind dizolvarea societății comerciale la împlinirea termenului stabilit pentru durata acesteia”, Revista de Drept Comercial, nr. 6/1997

Vivante, C. (1929). Tratatto di diritto commerciale, ediția a V-a, Vallardi, Milano

*** Tribunalul Bucureşti, Secția comercială, Decizia nr. 4717/12.12.1997 